Received 2 June 2020; accepted 18 March 2021

Available online 25 March 2021

\title{
Using Smart Technology in Conservation of The Ancient Egyptian Monuments from Environmental Impact and Anthropic Factors
}

\author{
Gehan Ahmed Elsayed \\ Associate prof. Head of Architecture Department Modern University for Information and \\ Technology \\ gehanelsayed2@yahoo.com
}

\begin{abstract}
The word "historical realm" refers to culture and identity. Which must be protected, but monuments, in particular, are subject to numerous types of deterioration. Traditional restoration techniques, on the other hand, do not show significant results or continue for long periods of time.

The lack of smart approaches in managing projects in Egypt's valuable historical realm, especially the restoration of the Saqqara pyramids and the Karnak temple, is a liability issue. Meanwhile according to the literature review, nanomaterials and smart systems can help to avoid deterioration and share efficiently in restoration applications.
\end{abstract}

So, the paper aims to look for novel aspects to manage historical monument restoration projects.

The paper is based on two methodologies: First is a measurable one that reflects the key technical aspects that can be used to restore Egyptian monuments efficiently. Second, an empirical deductive approach to ensure the effectiveness of modern technical materials and their neutral impact on the material's authenticity.

Finally, the paper concludes that; nanomaterials have great benefits that can really help in solving many of the problems that current techniques face in terms of enhancing the protection and restoration of damaged stones. Smart systems also have a noticeable impact on the restoration process, as enhancing the quality of all phases of the process and assist in the improvement of monumental preservation performance. this result will help to establish approaches to manage the restoration of the historical realm.

\section{Key words:}

Technologies, Nano materials, smart systems, heritage significance, efficient preservation.

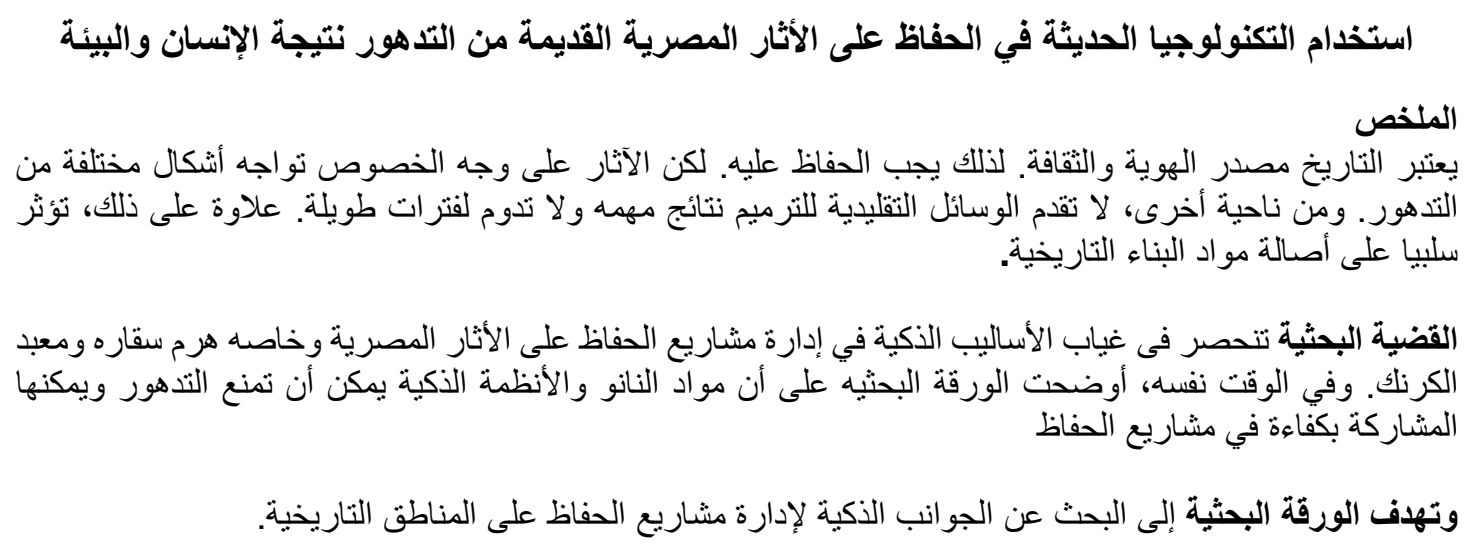




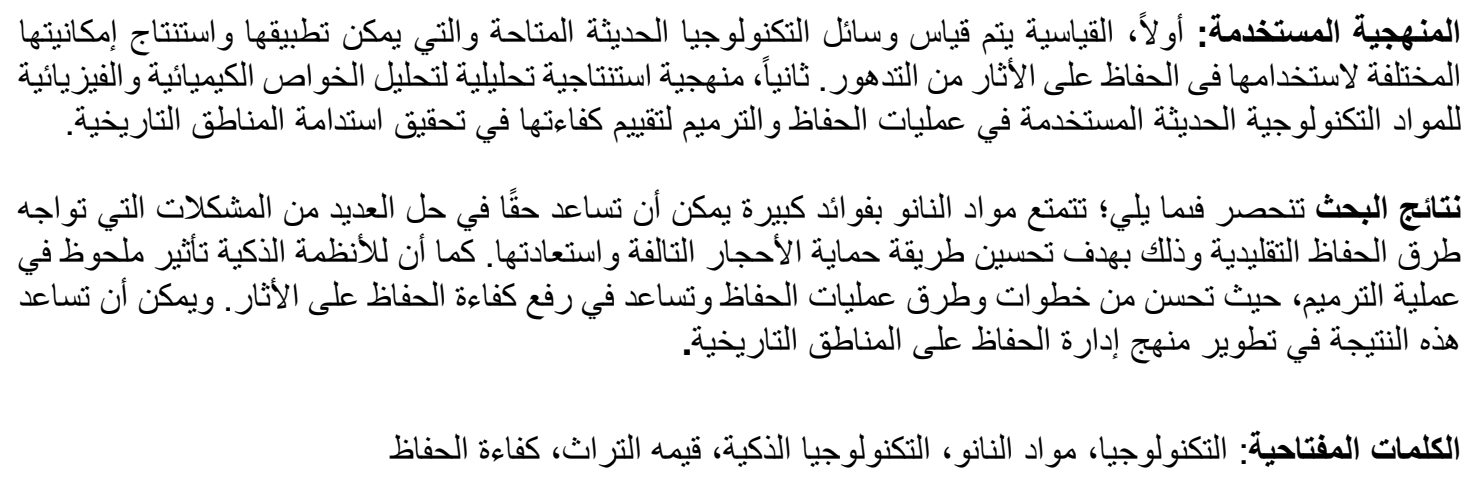

\section{INTRODUCTION}

Most of the ancient Egyptian monuments are suffering from deterioration and dangerous condition Saqqara step pyramid is considered as one of the oldest stone structure \& the first royal tomb in the history, now it is suffering from the collapse of some internal\& external parts. In Karnak and Luxor, the most important temples of ancient Egypt, numerous damage engravings caused by visitors, raising dampness is deteriorating the wall painting.

The paper suggests a new site management system to conserve the ancient Egyptian monuments from deterioration and collapse. The new system uses a non-classical analysis of routine procedures used by local authorities to conserve and save Egyptian monuments at risk. Documentation, monitoring to control the sites and some items used in the smart buildings which are the main items of the suggested site management systems giving an early indication for endangered points and Anthropic Factors. Egyptian Supreme Council of Antiquities (SCA), the responsible authority for the archaeological sites in Egypt, has more than one conservation strategy to consolidate, and consequently, save them. [To achieve its goals, it formulates and implements all policies concerned with antiquities, issues guidelines and permits for the excavation, restoration, conservation, documentation, and study of sites and monuments; and manages a country-wide system of antiquities museums]. But using these strategies in the proposed mission needs some studies about the technological development of materials and systems to justify their efficient role especially when using modern technologies that don't affect the significance of architectural heritage.

Thus, the research will be divided into three main parts to investigate the hypotheses stated below :

1. Evaluating the effectiveness of Nanoparticles as a consolidating and protective material for calcareous stone monuments. This was because of the way that it gives a general change in the attributes of the stone, expanding attachment and water-repellent properties in the treated surfaces, and causing no obvious shading changes on the international case studies.

2. Assessing the role of, Microclimatic sensors which is a valuable tool for monitoring historical monuments. Its value was shown in estimating variations in humidity, and in its ability to warn about the presence of soluble salts as shown in the international case studies

3. Conclusion 


\section{MEASURING THE ASPECTS OF NANOTECHNOLOGY IN CONVERSION OF CULTURAL HERITAGE}

Long time ago, while the development in material science was taking place, important nanostructures materials were generated. Lately, preservation of architectural heritage was based mainly on the traditional restoration and conservation techniques. ( Bernard $\&$ Feilden 2003) Often, these techniques, such as the use of artificial polymers, lose the vital integration with the original surface and sustaining performance. Now, Nanomaterials are being used to preserve and restore architectural heritage in order to enhance the mechanical properties and restoration of damaged building materials. Consolidation is one of the most important stone heritage preservation techniques. This technique is used to enhance the mechanical properties of materials. Consolidation treatments are the riskiest defense actions due to their inefficiency and the probability to cause undesirable impacts; for example, the loss of the feasible surface which is to be protected. This effect clarifies the different stone consolidation inquiries which were mentioned above. The use of Nanotechnology in architectural monuments preservation is characterized by the possibility of consolidating products that are highly penetrable beneath the stone substrate in a homogenous way. Moreover, when particles have measurements of about 1-100 Nanometers, the mechanical properties of materials change entirely from those at greater scales. Throughout this, Nanomaterials have larger area than equivalent masses of larger scale materials, which enhance their mechanical properties. Moreover, because of the particle size, these nanomaterials show the possibility to penetrate deep into deteriorated stone. [ Bernard \& Feilden 2003]

On the other hand, environmental pollution caused from the precipitation of organic materials and other pollutants on the stone surfaces, greatly increases the external deterioration of archaeological sites and its monuments as shown in SAQQARA PYRAMID case study.

\section{HISTORICAL BRIEF DESCIPTION OF SAQQARA PYRAMID}

It is located at Saqqara area - known to ancient Egyptians as The Pyramid of Djoser (or Djeser and Zoser), or Step Pyramid (kbhw-ntrw in Egyptian) at about $35 \mathrm{~km}$. southwest of Giza \& it's one of the parts of the royal complex of king Zoser. Minister Imhotep has been called: architect, doctor, sage, astronomer $\&$ high priest.The idea at first was to build a royal tomb like a terrace, but Imhotep was influenced by religious ideas which made him convert these ideas into a stepped pyramid, and to represent the ascending of the king to the god of the sun \& the sky world.The Step Pyramid has been thoroughly examined and investigated over the last century and it is now known that the construction process went through many different stages and there were a few false starts. Imhotep seems to have first begun building a simple mastaba tomb. The highest mastaba was 20 feet (6 meters) but Imhotep decided to go higher. Investigations have shown that the pyramid began as a square mastaba, instead of the usual rectangular shape, and then was changed to rectangular. Why Imhotep decided to change the traditional rectangular mastaba shape is unknown, but it is probable that Imhotep had in mind a square-based pyramid from the start. [Mark, j. 2016] 


\subsection{Causes of Deterioration and Damages to Cultural Property}

Through the documentation of the archaeological sites, the main items that cause damage and decay to culture heritage in Egypt are the environmental impact, ground water level and Anthropic decay problems, and these are the most effective factors that cause the deterioration of ancient Egyptian monuments. Anthropic factors cause damage by vibration: The step pyramid exposed to dangerous vibration due to explosions done in some quarries near the site referring to the data documented by the Institute of Geophysics Sciences in Helwan city. Internal pollution, the visitors and the archaeologists inside the tunnels cause high rate of $\mathrm{CO} 2$ and high moisture. Excavations, the digging for search for the unknown using non-professional methods. [Winkler,1988]

\subsection{Description of The Step Pyramid}

A team prearranged by Supreme Council of Antiques have stepped in to document the condition of the step pyramid in preparation for its restoration and preservation, so, we can describe the state of the pyramids as below.

\subsubsection{From outside}

The step pyramid was built with the figure of six terraces above a tunnel which goes down to the place of burial. The six terraces of the pyramid decrease in size until they reach a height of $60 \mathrm{~m}$. The pyramid's base is rectangular of dimensions $130 \mathrm{~m} \times 110 \mathrm{~m}$. The height of the first terrace is $8 \mathrm{~m}$

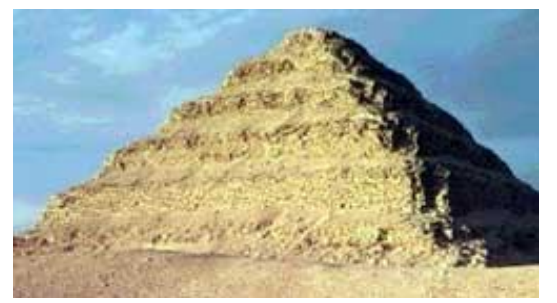

figure (1) step pyramid source: (step pyramid, 2021)

Approximately $8 \mathrm{~m}$ and each terrace is higher than the previous one by $2 \mathrm{~m}$. The Pyramid is encompassed by a rectangular encased divider that measures $277 \mathrm{~m}$ by $544 \mathrm{~m}$, generally destroyed today, yet it was originally $10 \mathrm{~m}$ high. You can see parts of it today. The vast majority of the external covering of the pyramid is gone and sooner or later a few sections of the principle building will vanish. The eastern side offers the best view; however, it can also be seen from the north and south. The first terrace from the stepped pyramid was the first squared royal tomb, each side is of length $63 \mathrm{~m} \&$ its height is $8 \mathrm{~m}$. It was constructed from stone which was cut down from quarries of Saqqara. However, the external coverage stones for this terrace or the other terraces were built above the first terrace later on. (Figure 1). (Magli 2009)

\subsubsection{From inside}

The main important internal parts

The main shaft: The height of the vertical square shaft is approximately $28 \mathrm{~m}$ and each side of it is $7 \mathrm{~m}$ long.

Tomb chamber: The tomb chamber is approximately $3 \mathrm{~m}$ in length and $2 \mathrm{~m}$ both in width and height and was built entirely of pink granite stone from Aswan.

It is located at the bottom of the main shaft. This room can't be reached except from an opening in its ceiling, and this opening is replicated in another room above the first one, 
but it was demolished \& never encountered till now. This opening was closed by a large stopper made of granite.

Tunnels: There are many tunnels; the important one is a tunnel heading towards the north from the shaft. Its ceiling is $7 \mathrm{~m}$ below the surface of the ground. The tunnel continues for a distance of about $21 \mathrm{~m}$ towards the north.

Above the burying room there are four corridors connected with each other by passes. These corridors are located under the earth's surface \& they were constructed in order to put the funeral furniture $\&$ the large vessels which were buried with the king. Some of these corridors were lined with blue tiles.

Statue of king Zoser: On the north-western side of the pyramid exist a little room worked with an inclination point like the pyramid itself. There, was discovered an excellent statue of ruler Zoser made of limestone. This statue was moved to the Egyptian exhibition hall in Cairo and was supplanted by an imitation.

Eastern walls: On the eastern side of the pyramid we find eleven wells, each one has a depth of $32 \mathrm{~m}$. Under each well there is a corridor directed to the west under the first terrace having a length of 20m. (Figure 2 ,3) (Magli 2009)

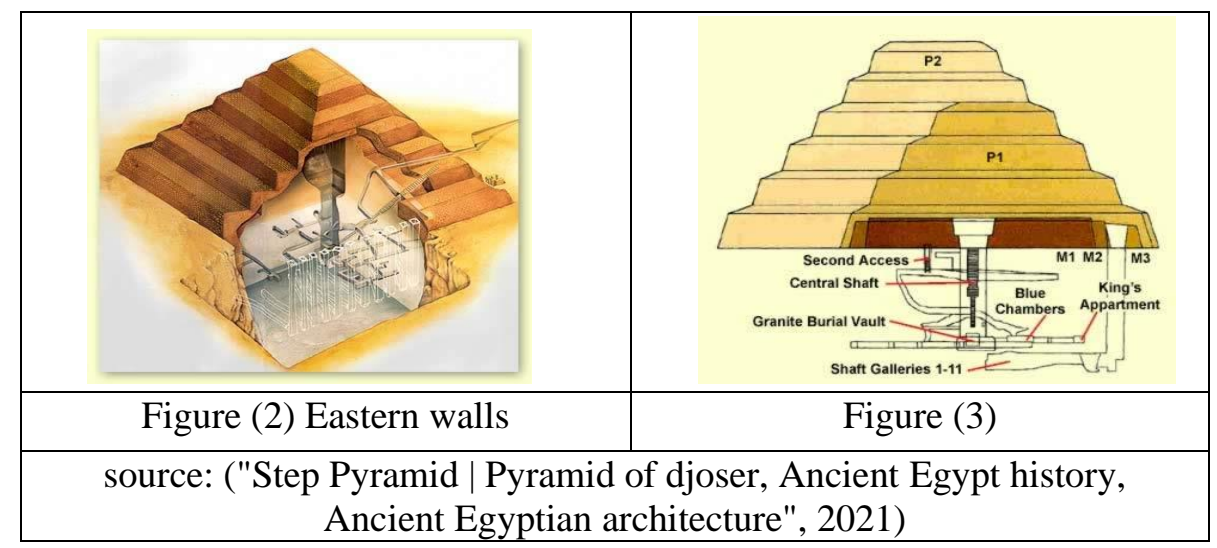

\subsection{Documentation of Deterioration (Analytical Description).}

The step pyramid suffered greatly over the four and a half millenniums since it was constructed. It has been deteriorated by earthquakes and it is now threatened by modern pollution, the environmental impact and Anthropic factors. Major cracks were recorded in the subterranean chambers, and stones have begun to fall down from both the exterior and the interior of the pyramid

Nowadays, Saqqara step pyramid is suffering from the collapse of some internal \& external parts.[ Mark 2016]

\subsubsection{From outside}

Analytical description study had been done by a team from Cairo University and Supreme Council of Antiques in 2007 to record the state of the outward appearance of the pyramid to define the deteriorated parts, the lost parts, the parts covered by sand and dusts and the parts that had been restored before. See Figures $(4,5,6,7)$.

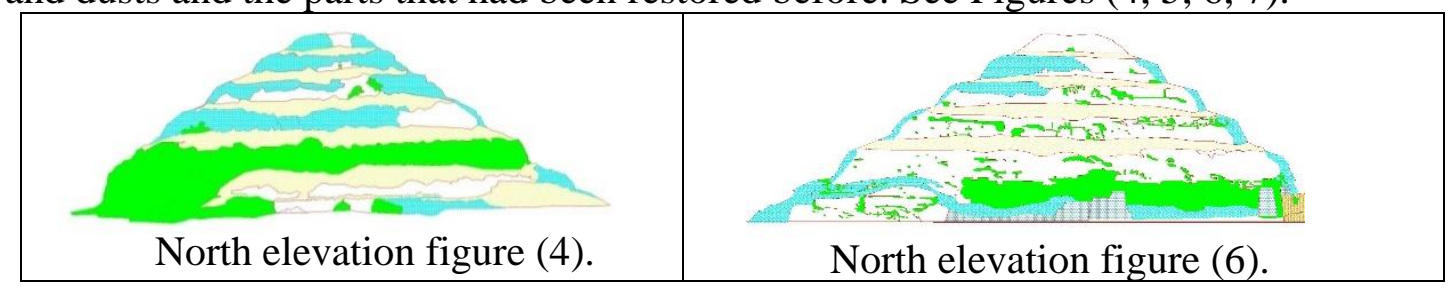




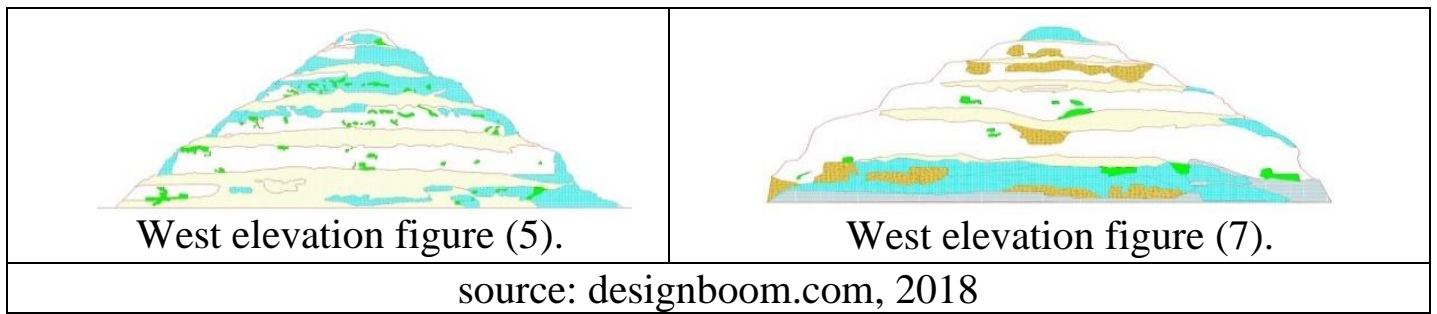

Table (1): Analysis of the area in meters

\begin{tabular}{|c|c|c|c|c|c|c|}
\hline $\begin{array}{l}\text { Analysis of the areas } \\
\text { in meter }\end{array}$ & $\begin{array}{l}\text { North } \\
\text { elev. }\end{array}$ & $\begin{array}{l}\text { South } \\
\text { elev. }\end{array}$ & $\begin{array}{l}\text { West } \\
\text { elev. }\end{array}$ & $\begin{array}{l}\text { South } \\
\text { elev. }\end{array}$ & $\begin{array}{l}\text { Total } \\
\text { area }\end{array}$ & $\begin{array}{c}\% \text { of total } \\
\text { area } \\
\text { recorded }\end{array}$ \\
\hline Untied rocks areas & 719 & $V T V$ & $\wedge \backslash \wedge$ & $v \leqslant 0$ & 2989 & $30.4 \%$ \\
\hline Lost parts areas & 19. & 879 & 177 & 01 & 1883 & $19.3 \%$ \\
\hline $\begin{array}{c}\text { Deteriorated rocks } \\
\text { areas }\end{array}$ & 71 & - & rᄉr & - & 451 & $4.5 \%$ \\
\hline Covered with sand & $\mid 1 K 1$ & VOA & $\begin{array}{c}1 \leq 7 \\
1\end{array}$ & 71. & 3952 & $40.1 \%$ \\
\hline Restored rocks areas & & $r \cdot \Lambda$ & & $r \leqslant \Lambda$ & 556 & $5.7 \%$ \\
\hline
\end{tabular}

Source: Supreme Council of Antiques in 2007 record the state of the outward appearance of the pyramid

\section{The analysis points out that:}

- The untied rocks areas are intense in the first step and in the top and the corners of all steps.

- The areas which have damaged parts of its rocks mainly are in the lower parts (the reachable areas) in the north and south elevations where the two entrances are.

- The deteriorated rocks are in the north and west elevations because of the effect of the wind action.

- The Areas covered with sand and dusts are in between the steps and it reserved the rocks behind it safe. (Hasan Fahmi,2007)

\subsubsection{From inside}

- Some of the tunnels in the pyramid show signs of deterioration. Evidence of this is the crumbling of masonry at the top of the walls of the tunnel and the development of longitudinal cracking in the roof of the tunnel.

- It is difficult to inspect whether this cracking has been caused by ground acceleration due to earthquakes, but it is not a seismic area. Due to the data documented by the Institute of Geophysics Sciences in Helwan city, the archaeological site was subjected to vibration due to explosions done in some quarries near the site (approximate distance of $16 \mathrm{~km}$ ). The heavy mass of masonry above the tunnel would be mobilized by earthquakes and fracture would develop at weakest point of the structure, namely the tunnels of the passageways. It is important to note that any movement that has taken place did not lead to subsequent localized failure and a partial collapse of the passageways. 
- A temporary wooden support had been erected but it can't resist the movement and it collapsed in some parts, but no documents have been found for when and how it has been executed Figures $8(a, b)$.

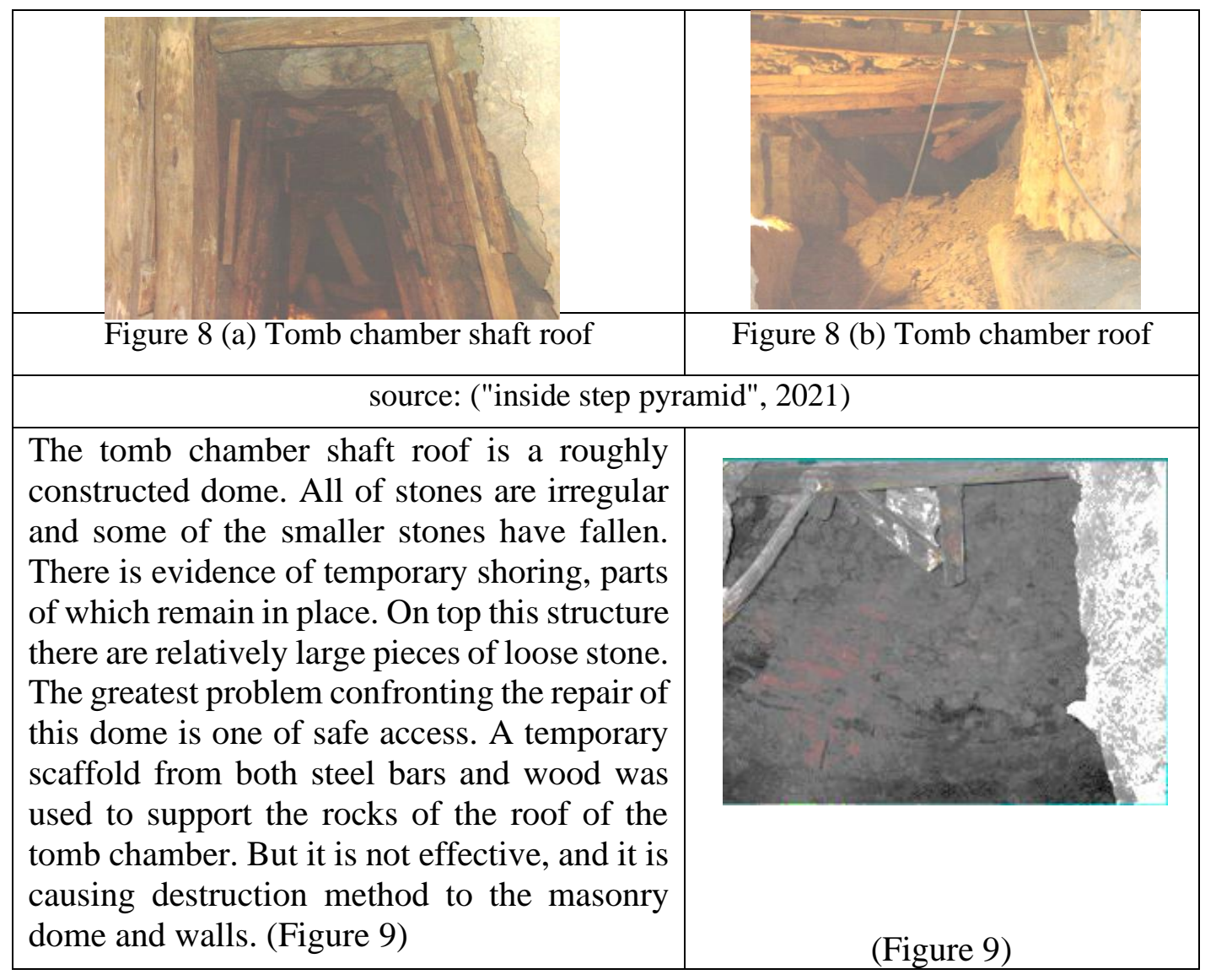

\section{NEW NANOMATERIALS USED FOR STONE CONSERVATION APPLICATIONS}

This research focuses on the current state of knowledge in the application of different types of Nanoparticles for the improvement of conservation strategies of the SAQQARA PYRAMID. The influence of experimental synthesis parameters can modify the morphologies, particle sizes, and crystalline structures of the nanoparticles obtained and therefore has to be analyzed. The following table summarize the most common consolidated materials that show a good evidence when used in conservation process and their effects [Mariana et al 2017]. 
Table (2): The most common consolidated materials used in conservation process and their effects:

\begin{tabular}{|c|c|c|}
\hline & Consolidants & Effect \\
\hline 1 & Alcalo-silicates & Accumulation of silica in the limestone blocks \\
\hline 2 & Silico-fluoride & $\begin{array}{l}\text { On the outer layer,silicon tiles may form } \\
\text { acement crust,a layer of greater } \\
\text { hardness. Those solutions are no longer } \\
\text { currently prefered. }\end{array}$ \\
\hline 3 & Alkaline hydroxides & $\begin{array}{l}\text { The impact of consolidation is still insufficient } \\
\text { and requires repeat treatment to maximise } \\
\text { profit.The process is relativly uneconomical. }\end{array}$ \\
\hline 4 & $\begin{array}{l}\text { Strontium and barium } \\
\text { hydroxides }\end{array}$ & $\begin{array}{l}\text { These solutions seem more efficient than } \\
\text { calcium based,but experts believe in durability } \\
\text { issue of treated stones and its applications to } \\
\text { architectural heritage }\end{array}$ \\
\hline 5 & $\begin{array}{l}\text { Inorganic builders (aluminum } \\
\text { sulfate, phosphoric acid, zinc } \\
\text { stearate and aluminum } \\
\text { stearate, phosphate and } \\
\text { hydrofluoric acid ) }\end{array}$ & $\begin{array}{l}\text { Apparent penetration into the stone pores. } \\
\text { Hazard to microbial community }\end{array}$ \\
\hline 6 & $\begin{array}{l}\text { Alcosilanes (or alkoxylans). } \\
\text { Increased, mechanical } \\
\text { strength has also been } \\
\text { reported with approx. } 20 \% \text { of } \\
\text { the silicon tiles treated, which } \\
\text { is already performing }\end{array}$ & $\begin{array}{l}\text { The smartest materials with an enhancing } \\
\text { function. A deep penetration of silky tiles into } \\
\text { pores. The alkoxylans penetration in the stone } \\
\text { takes plac at a depth of } 20-25 \mathrm{~mm} \text {, which } \\
\text { means more than the inorganic structure. }\end{array}$ \\
\hline 7 & $\begin{array}{l}\text { Acrylic polymers (methyl- } \\
\text { methacrylate, methyl-acrylate, } \\
\text { ethyl-methacrylate and butyl- } \\
\text { methacrylate). }\end{array}$ & $\begin{array}{l}\text { All these items enhance the rigidity of the } \\
\text { treated stone layer, but their color is unstable } \\
\text { due to the action of the above-mentioned } \\
\text { agents. }\end{array}$ \\
\hline 8 & $\begin{array}{l}\text { Vinyl polymers (polyvinyl } \\
\text { chloride, polyvinyl acetate, } \\
\text { polyvinylchloride-chlorinate) }\end{array}$ & $\begin{array}{l}\text { Polyvinyl acetate can give the stone's surface a } \\
\text { glossy-glassy appearance. On the other side, if } \\
\text { the polymers were poorly diluted in the solvent } \\
\text { a screen of formed layers is formed } \\
\text { maintaining the salts and moisture in the stone. }\end{array}$ \\
\hline 9 & The polyurethanes & More effecient treatment, for warmth and light \\
\hline
\end{tabular}

Source: Mariana Ion,R., et al 2017 


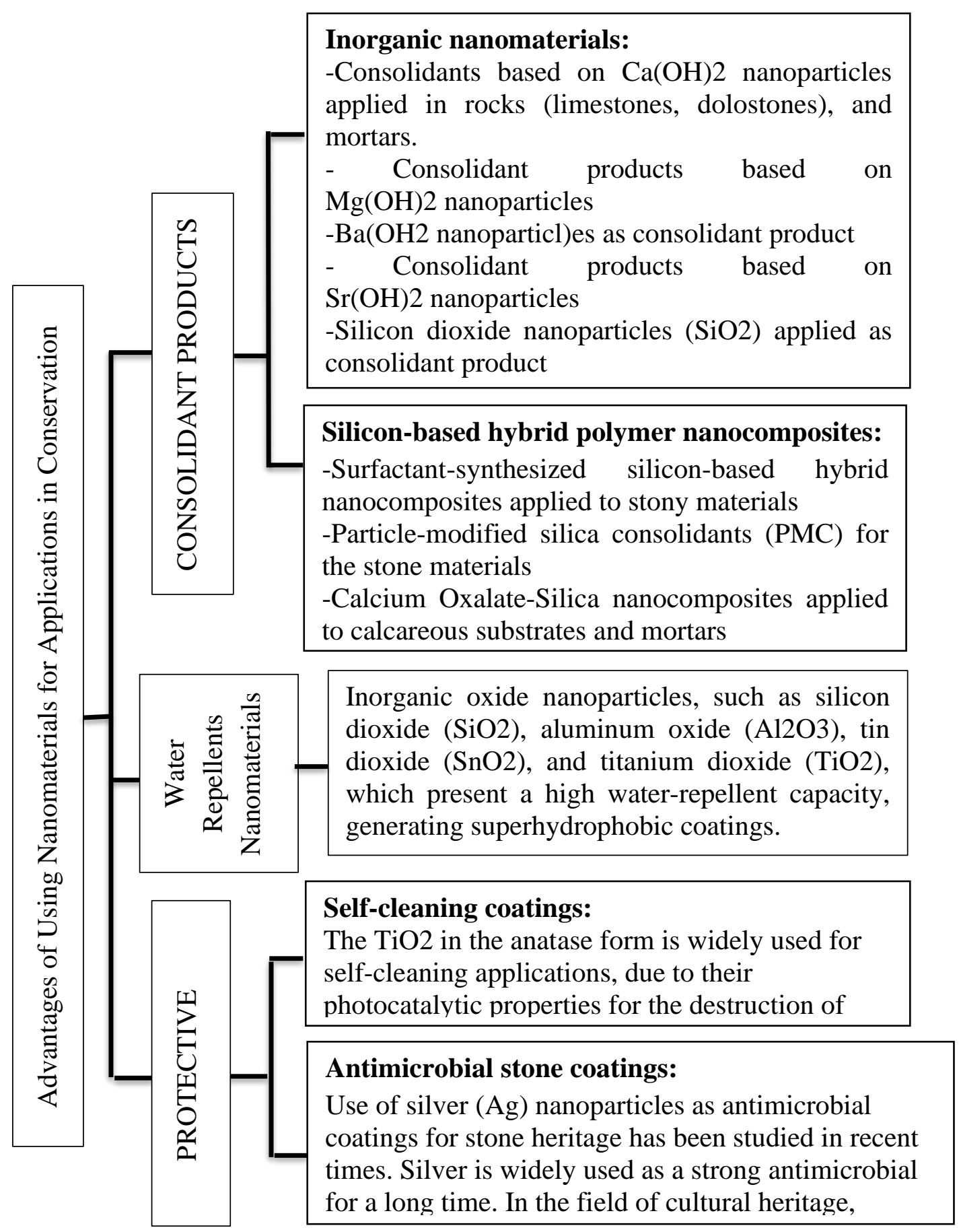

(Figure 10): New nanomaterials for applications in conservation and restoration of stony monuments Source: [Rabanal et all.2017]

Since 2010, All Saints Church has been restored using nanotechnology, and, as shown below, it has shown significant results for restoration. 


\subsection{All Saints Church, Little Kimble England}

Church is located in Oxford Obricih in the neighborhood Wycombe, England, is located within a 5 - mile $(8.0 \mathrm{~km})$ to the south of Aylesbury,

\subsubsection{Causes of deterioration and damages to the church}

Restoration work began in 1930, with the restoration of the walls of the church covered with wax and was considered the best treatment time, but with the passage of time has shown this type of restoration failing in the face of the various factors of moisture and salts exposed archeological buildings in England constantly, where through the viewfinder Studies the appearance of cracks and crevices walls which shows the separation between the layers of stone and gypsum user.

* the presence of insects and dirt Kanakp bat on graphics that distinguish stone walls Church, which was produced by the presence of small pits and cracks walls and the disappearance of a large portion of those graphics effect, as shown in the [Figure11]

(fig11): A graphics on the stone walls of the church, and the picture is clear from the appearance of small cracks and open pit wall.

source: (All Saints Church, Little Kimble England, 2021)

\subsubsection{Restoration methods with nanomaterials used to the church}

* In 2010 it began to take new measures to maintain
the church, and through the use of calcium hydroxide
in the Nano- scale alcohol commentator Nano
hydroxide calcium suspended in alcohol and identify
places to be injected as shown in [Figure (12] (All
Saints Church, Little Kimble England, 2021)
treatment walls of moisture and so drained by
injecting various cracks textured industrial
methylated spirits (IMS), also facilitates the
penetration of Nano material inside the wall process,
as can be seen in the [figure 13] Paul D'Armada,
$\begin{aligned} & \text { Elizabeth Hirst," Nano-lime for consolidation of } \\ & \text { plaster and stone ", journal of architecture } \\ & \text { conservation Montfort university ,London,2012,p.77 }\end{aligned}$
$\begin{aligned} & \text { strengthen calcareous stone walls and it injects } \\ & \text { minute cracks textured calcium hydroxide in the } \\ & \text { nanoscale, as evidenced in the [figure14] }\end{aligned}$




\section{MEASURING THE ASPECTS OF SMART SYSTEM IN CONSERVATION OF CULTURAL HERITAGE}

Architectural heritage can be affected by different physical elements. In this manner, checking parameters engaged with the decay procedure, mainly temperature and relative stickiness is helpful for protective preservation. In this examination, we propose microclimate equipment to put inside the structures of social architectural heritage to survey the conduct of inside. Temperature and relative humidity in connection to outside climate conditions open hours, and inside plan. Long haul observation of these constraints is of enthusiasm for terms of protection and diminishing the expenses of upcoming preservation techniques. [Harmol 1961]

\subsection{Historical Introduction}

They are the most important temples in the ancient Egyptian monuments. Karnak is actually the modern name of the site. Its ancient name was Ipet-isut. This tremendous complex was manufactured and developed over a thirteen-hundred-year time span. Luxor temple is located in the center of modern Luxor, and approximately $3 \mathrm{~km}$ south of Karnak. [Harmol 1961]

\subsection{Documentation of Deterioration and Damage to Cultural Heritage}

Through the documentation of the archaeological sites, the main items that cause damage and decay to culture heritage in Egypt are the environmental impact, groundwater table and Anthropic factors, and they are the most effective factors causing the deterioration of ancient Egyptian monuments. [Ismail 2003]

\subsubsection{Effect of water dampness variation}

Karnak and Luxor temples have suffered from water dampness. Recently, attention has been paid to this problem, especially after construction of Aswan high dam. This caused increase in ground water level. [Kiersch\& Treacher 1955]

\subsubsection{Effect of water variation on foundation.}

Major projects of ground water control were performed by (Water research center, ministry of public works and water resources and the Swedish research center SWICO) in 2002 to reduce ground water level. After one year of continuous monitoring of the monuments using high accurate devices, the mentoring systems indicate that several parts of the temples are in bad condition and that there is risk of damages if only small differential settlements occur. Especially the Eastern Pylon of Luxor temple is emphasized, where the initial movements are recorded to have occurred between 1959 and 1960 when the existing sand cover was removed. [P.YA. Polubarinova-Kochina, 1962] By that the lateral support for the walls disappeared and the allowable bearing pressures for the temple structures were also reduced. The constant high ground water table since 1970 is from a statical point of view. The consolidation settlements will occur when the ground water table is lowered 2-3 $\mathrm{m}$ to reduce water capillarity rising. However, there will be some movements because there will be different settlement in the temple parts. Other possible ways to determine the magnitude of movements suggest that movements that happen are very dangerous. [Figure 15,16,17]

[Matkowski 2017] 


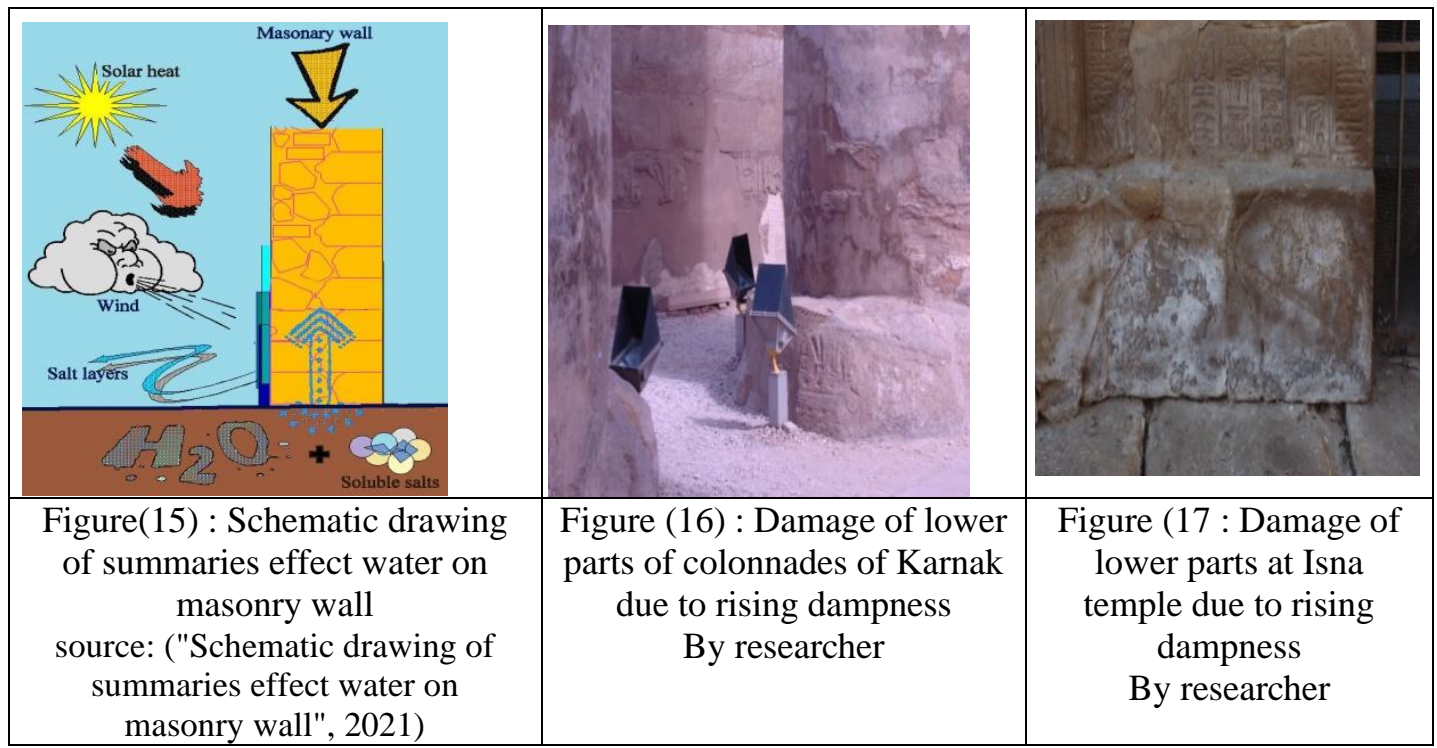

\subsection{Smart Systems Used in Detection of Damages}

Climate change and ground water pose serious threat to cultural heritage. different factors, for example, contamination can likewise extremely influence the outside exteriors of memorable structures, and accumulations safeguarded inside notable structures are additionally in danger. Keeping in mind the end goal to handle these issues, it is basic to create prescient models, early warning devices, and notable materials, development. This would monitor protection and the effect of ecological change on architectural heritage as well as helping to develop rules, standards and procedures for landmark preservation and protection.

\subsubsection{Common (GPR)}

Ground penetrating radar (GPR) Programming improvement has been engaged, much of the time, to the upgrade of radar pictures to encourage information explanation. A standout amongst the most well-known GPR applications is the finding of harms in Cultural Heritage. Numerous Inheritance structures are also harmed because of ecological causes, for example, dampness and ground water. Moreover, the age of these structures, and in addition conceivable outside risks, cause the presence of unmistakable harm in the landmark, for example, sodden patches, splitting, and separation of materials. Frequently, harm to the structure has an augmentation more prominent than those seen in visual assessments. Through these cases, GPR is connected as an effective instrument, for the most part as a consolidated philosophy. This system has been demonstrated proper to distinguish harms in various individuals from notable structures. Much of the time, GPR is connected to identify inside splits and unfilled joints in brick work structures. [Figure 18,19] [Barrile \& Pucinotti 2005]

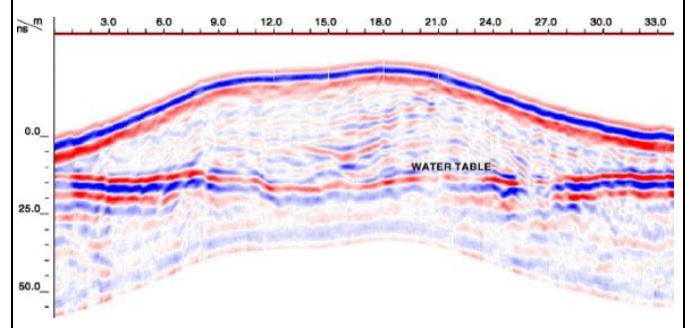

Figure (18): Depth to the water table record by radar. source: ("Depth to the water table record by radar ", 2021)

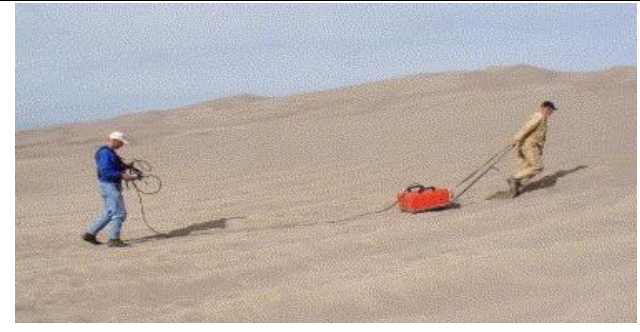

Figure (19): Ground penetrating radar (GPR) source: ("ground penetrating radar (gpr)", 2021) 


\subsubsection{Canonical Bi-plot as tool to detect microclimates changes}

The Canonical Biplot is similar to MANOVA (Multivariate Variance Analysis), which permits simultaneous plots of the different groups to be compared, and the different variables being analyzed Recently, the information of absolute dampness and temperature from various sensors in the internal and external portions of the landmarks are taken to describe diverse miniaturized scale conditions in it through interims at that point examined estimations of the sensors at regular intervals, to identify the distinctive microclimates exhibit. To stay away from the impact of occasional time, the sensors were put outwardly (ecological station) and inside the monument. [Talegon 2012]

\subsubsection{The (MHS) project Monitoring Heritage System}

The MHS project (Monitoring Heritage System) is imagined as an observing framework adjusted to the notable and imaginative architectural heritage that has been introduced and tried since 2005 by Santa Maria la Real Foundation, the System parts. [López 2012] as the following.

- Specific monitoring system, comprising of gear for estimating and recording ecological constraints, basic and security, particularly created to conquer the issues of establishment in architectural heritage.

- Basic Data Transmission System, to create a successful and institutionalized categorization in information transmission. - Database, as the outcome from the connected examination consider, in light of the portrayal of the diverse target materials from the record information enrolled by the framework.

- Predictive Diagnostics Tool. Programming in light of the usage of scientific calculations created by Statistical Process Control (SPC) and Pattern Recognition. User's Application. The interface collaborates with the last client or chief, giving pertinent data and conceivable changes and alterations in the framework.

- Actuators. Devices that can be worked by the framework or by the client to control and manage the frequency of specific parameters. The MHS insight lies in the framework ability to distinguish and foresee dangers or potential harm and initiating activity gadgets consequently or making particular proposals for activity, with a specific end goal to keep up the ideal conservation of heritage. Figure 20

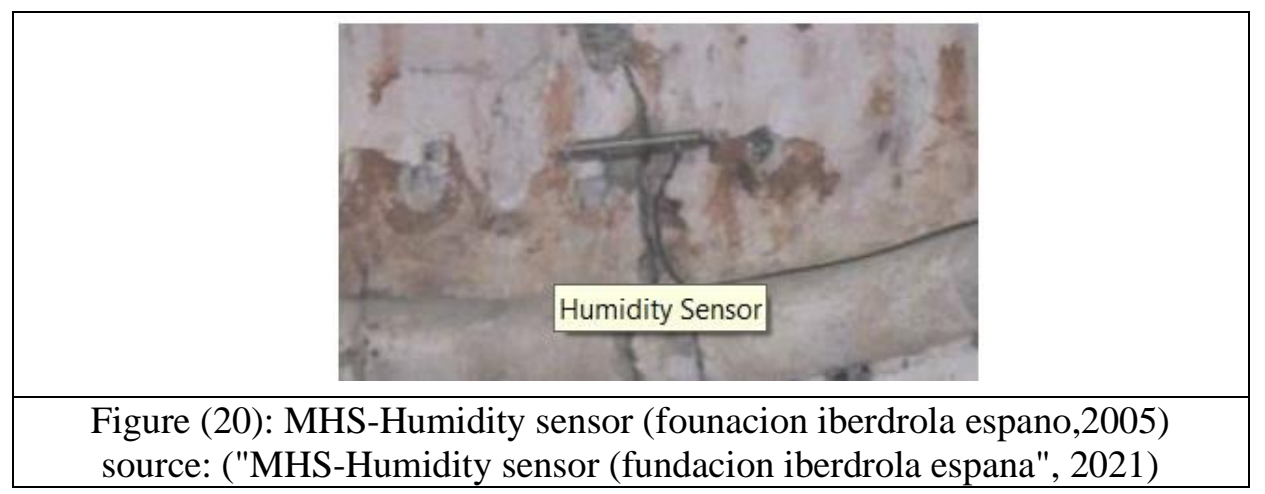

\subsubsection{The terrestrial laser scanner system}

RIEGL Z390i (RIEGL, 2010) was the land base laser scanner system used for the detection. This scanner has a laser source that discharges pulses with an infrared wavelength of $1,500 \mathrm{~nm}$. The point estimate goes each second is 11,000 focuses. The flag force obtained from the sensor frame is registered in 8 bits [0 255]. 
A Nikon D200 camera was mounted on the laser. The Rescan Pro tool was used for predicting and inspecting the damp and moisture inside walls by the difference of shades that recorded on the camera result from the different laser wave lengths. [Allen et al., 2013] Figure 21

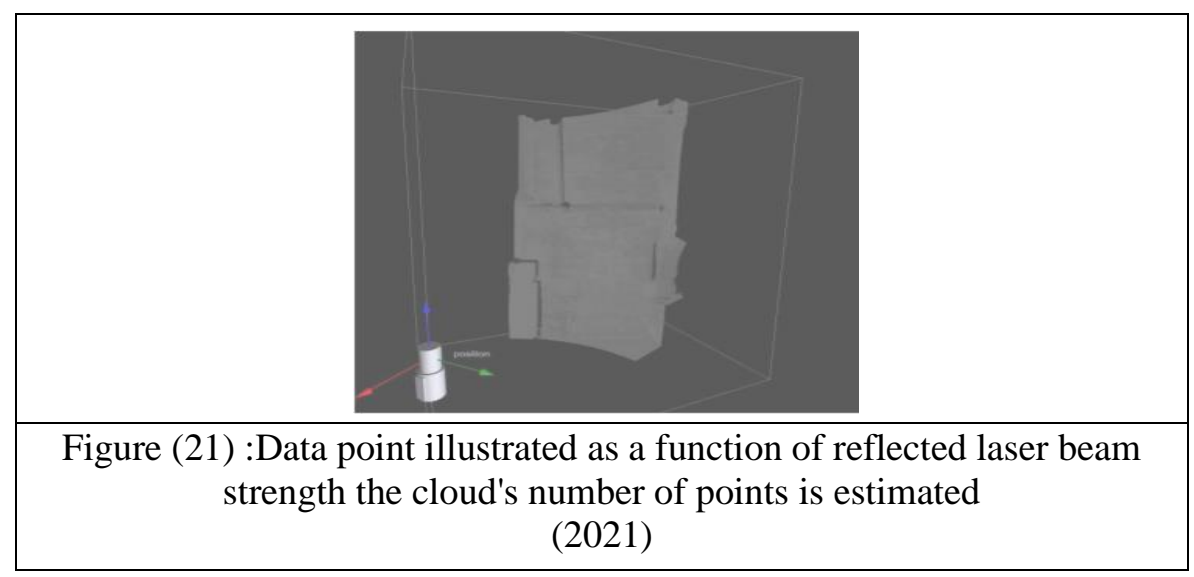

\subsubsection{Wireless sensor networks (WSN)}

Wireless sensor systems mainly used for long term monitoring process as long as it gathers cumulative data for the architectural heritage behavior throw time to predict the heritage behavior.

Dedicated software services provide:

i) Information gathering, to proficiently accommodate the various information rates and dependability needs of heterogeneous sensors;

ii) Information dispersal, to spread design changes and empower remote entrusting; .

( Barrenetxea et al., 2008) (Figure22) (a, b)

iii) Time synchronization, with low memory requests. which demonstrate that the framework is a viable device for evaluating the sanctuary strength, as it conveys information dependably (with loss ratios).

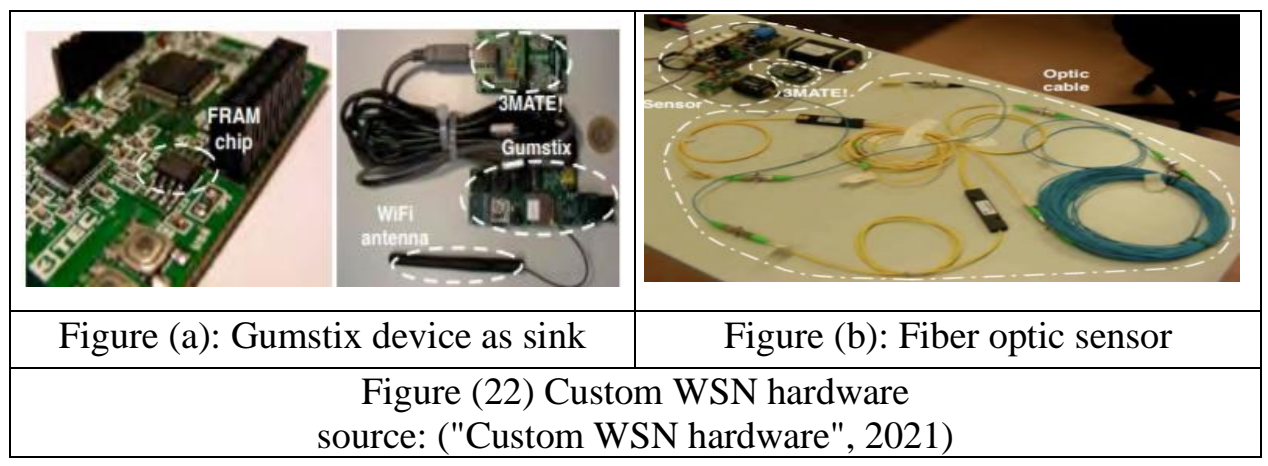




\subsection{Smart System Used in Conservation of international Case Studies}

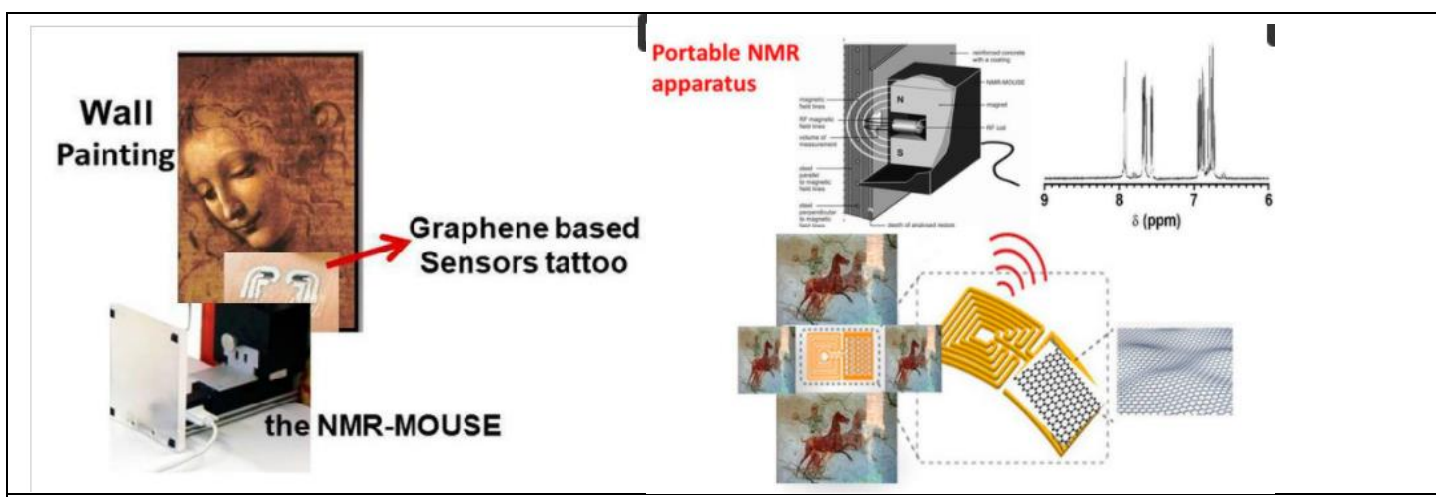

raphene-based tattoo/combined with the movable NMR apparatus, for several applications: sensors directly applied on cultural heritage surfaces (to identify the composition of black crust layers); actuators suitable to remove environmental black crust/patinas and to provide (for example, as a case study) free water molecules, having short relaxation time, essential to produce a significant NMR signal profile/spectra. [Tapete et. all, 2012] Figure 23 ("nmr spectrometer diagram", 2021)
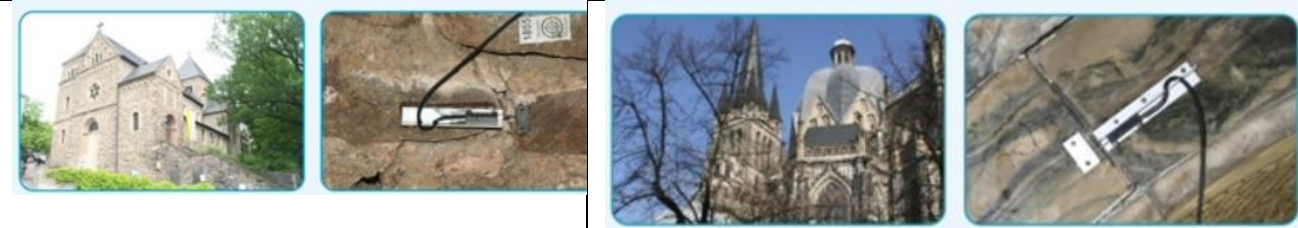

Church of the annunciatin of the

blessed virgin mary in Nazareth

World heritage site Aachen cathedral (charlemagne) Roman Catholic church in Aachen, Germany

Fully automatic recording of crack displacements, air temperature and humidity thanks to the high-resolution crack analysis sensor system and the revolutionary digital CMOSens ${ }^{\circledR}$ technology [Tapete et. all, 2012] Figure 24

("high-resolution crack analysis sensor system and the revolutionary digital CMOSens ${ }^{\circledR}$ technology - Google Search", 2021)
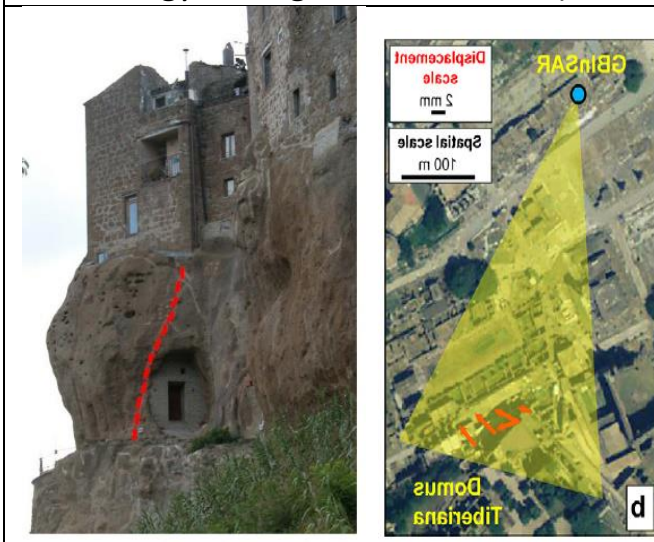

The area selected on the southern side of the pitigliano cliff italy. Deformometers were installed to monitor the joint (dashed line) which controls the wedge geometry. Spatial relationship with the overlying building suggests probable direct impacts on the preservation of the built heritage(Figure 25)

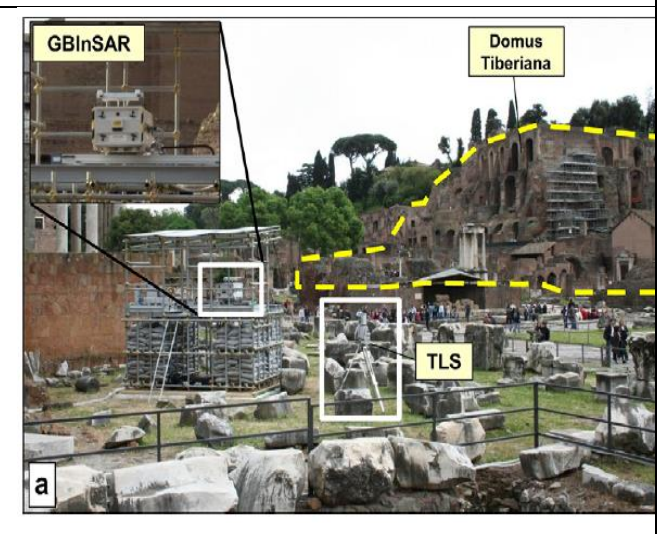

On site istallation and radar data acquisition of

Roman forum. The GBInSAR lisamobile, mounted on stable scaffoldings, with view centred on the domus tiberiana [dashed yellow line] Figure 26

Source: [Tapete, D., et. al, 2013] 


\section{THE SITE MANAGEMENT}

It is the integrated system, which monitors and documents the geological and physical characteristic changes of the site and the Anthropic factors. Some of the archaeological sites in Egypt follow the old traditional management methods to conserve the archaeological sites which depending on personal human skills and primitive tools to give a critical description of the present condition of the property and its OUVAI using physical attributes that will allow measurement of change over time. (Figure 27,28 ) (Rowberry 2012)

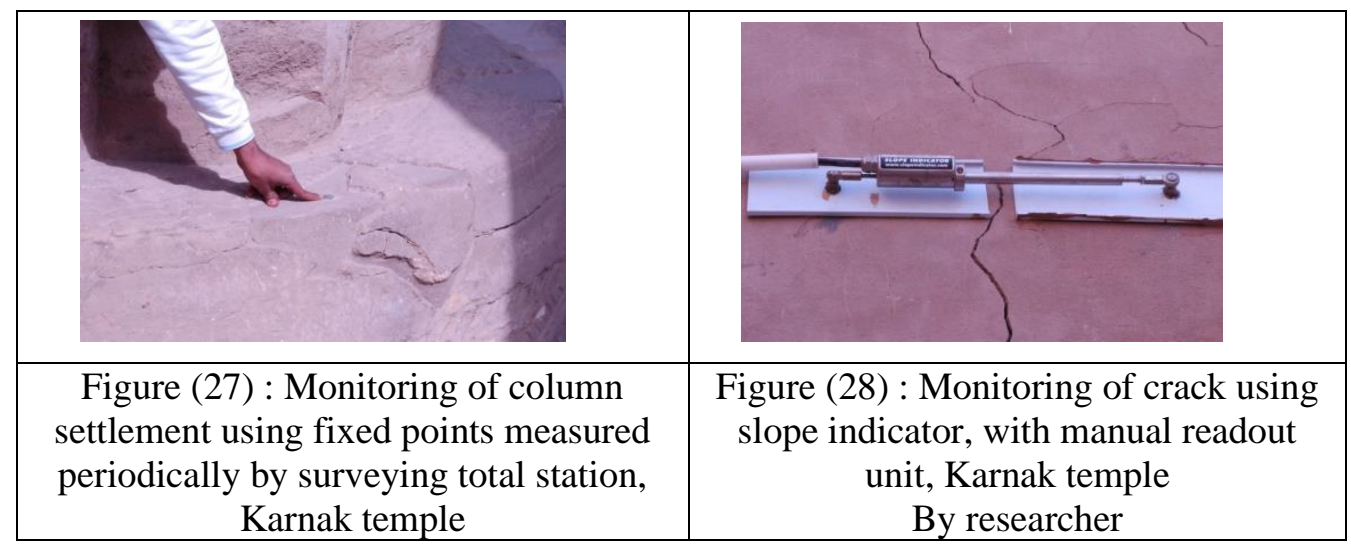

\section{The management system contains the technology of monitoring the changes:}

The previous technologies (sensors and methods) can gather the following information which must be attached to maintain management system that can save and monitor the change as :

- The ground water table level.

- The vibrations due to earthquakes and explosions done in the quarries near the site if found.

- The cracks and the deteriorated parts of the rocks and the masonry walls

- The moisture and salts in the rocks and the masonry walls and all the archaeological elements.

- The moisture and the air ventilation in the tombs, tunnels and closed areas.

- The visitors' reachable parts.

- The new excavation areas.

It could be done by using the previous micro metering devices active with sensors, smaller scale chips, miniaturized scale and nano-inserted frameworks, that will permit to gather, channel and deliver increasingly data locally.

\section{The management system exploring the new ways to deal with the significant causes of deterioration through:}

- The speed action to deal with the main causes of deterioration through minor or major projects.

- Controlling the visitors' roots and minimize accessible parts of the monuments.

- Controlling the number of visitors according to the degree of appropriate humidity and ventilation.(outdoor quality sensors)

- Exploring the appropriate lighting system to safe the monument . (day light sensors)

- Determine the importance of the site museum or the visitor centers if needed. 
- Determine the importance of the use of the digital models of the original monuments.(simulation: imitation, tests and models)

\section{CONCLUSION}

- To conserve and save Egyptian monuments in risk; Documentation and Monitoring should be the first step.

- Recording and Documentation of Saqqara step pyramid showed that it is suffering from the collapse of some internal \& external parts. Major cracks were recorded in the subterranean chambers, and stones have begun to fall down from both the exterior and the interior of the pyramid.

- Documentation and the mentoring systems showed also that several parts of Karnak \& Luxor temples are in bad condition and that there is risk of damages if only small differential settlements occur.

The use of nanotechnology applied to the field of stone heritage conservation creates opportunities for the development of conservation process with improvment material properties and novel interfaces. Such nanomaterials provide great advantages that could overcome several problems that exist in conventional treatments by creating new nanomaterials or traditional treatments with nanoparticles integration.

Table 3: The proposed Criteria which were to be used to reach the efficiency while conserving the heritage sites can be as follows:

\begin{tabular}{|l|l|l|l|l|}
\hline \multicolumn{2}{|c|}{} & \multicolumn{3}{|l|}{ The cues of efficiency for the materials } \\
\cline { 3 - 5 } \multicolumn{2}{|c|}{ The heritage conservation rules } & $\begin{array}{l}\text { Smart Materials } \\
\text { impeded in the } \\
\text { temples }\end{array}$ & $\begin{array}{l}\text { Eco nano } \\
\text { materials }\end{array}$ & $\begin{array}{l}\text { Smart } \\
\text { adaptive } \\
\text { materials }\end{array}$ \\
\hline $\begin{array}{l}\text { The safeties } \\
\text { of the } \\
\text { heritage site }\end{array}$ & $\begin{array}{l}\text { Smart } \\
\text { maintenance }\end{array}$ & $\begin{array}{l}\text { Smart } \\
\text { applicability in } \\
\text { the site }\end{array}$ & & \\
\hline $\begin{array}{l}\text { Reducing the } \\
\text { resources } \\
\text { used in the } \\
\text { heritage sites }\end{array}$ & $\begin{array}{l}\text { Efficient nano } \\
\text { material }\end{array}$ & & & \\
\hline $\begin{array}{l}\text { High quality } \\
\text { public realm }\end{array}$ & & & & \\
\hline
\end{tabular}

Source: researcher 


\section{DISCUSSION \& RECOMMENDATIONS}

- Nanotechnology is shown to have a noticeable effect in the cultural assets and construction field, enhancing the quality and increased efficiency of monumental preservation as clarifying in all saints church UK.

It is important to study the effectiveness, compatibility and durability of the new nanomaterials in order to avoid the use of insufficient treatments which change the style, physical and mechanical properties of the stone and cause new afflictions

- Documentation, Monitoring, and some items used in the smart buildings are the main items of the suggestion site management systems which gives an early indication for endangered points and Anthropic factors.

- It is the integrated system to monitor and document; the geological and physical characteristic changes of the site and the Anthropic factors, to re-distribute and control the rout of the visitor and the reachable parts of the archaeological elements of the sites to make it possible avoid and speed handle the causes of deterioration.

- It could be defined as the automation involved somehow that makes managing and operating the archaeological site more efficient.

\section{REFERENCES}

Allen, K. et al., (2013) "Interactive sensory objects for improving access to heritage" In Proceedings of the Human Factors in Computing Systems, 27 April 2013 ( pp. 2899-2902). Paris, France.

Barrenetxea, G. et al., (2008) "successful wireless sensor network deployments.in proc" of the 6th Int. Conf. on embedded net worked sensor systems(SENSYS),2008.

Bernard M. \& Feilden(2003) "Conservation of Historic Buildings," International Centre for the Study of the Preservation and the Restoration of Cultural Property (ICCROM), Rome 2003

Barrile, V. \& Pucinotti, R. (2005) "Application of radar technology to reinforced concrete structures" a case study. NDT E Int. 38, 596-604 (2005).

Kiersch, G. \& Treacher, A. " R.C. Investigations, a real and engineering geology Folsom dam project, Econ, Geol. vol. 50, 1955, (pp 271-310). central California.

Logan, \& William, S. (2007) "Closing Pandora's Box: Human Rights Conundrums in Cultural Heritage". In Silverman, Helaine; Ruggles, D. Fairchild (eds.). Cultural heritage and human rights. New York, NY: Springer. (2007).ISBN 9780387713137. OCLC 187048155.

López, E.( 2012) “ Desarrollo e innovación en los sistemas de gestión del patrimonio. MHS” (Monitoring Heritage System) In VIII International AR\&PA Congress, Valladolid-Spain 2012.

Magli, G. (2009)"Geometry and perspective in the landscape of the Saqqara pyramids" November 2009

Mariana, I. R. et al., (2017) "Regional Metallogeny of the New Hebrides and Mariana Back-Arcs" June 2017 Geochemistry Geophysics Geosystems 18:35 DOI: 10.1002/2017GC006813). Western Pacific.

Mark, j. (2016) “ The Step Pyramid of Djoser” published on 14 February 2016

Matkowski, z.(2017) "Analysis of the Moisture Content of Masonry Walls in Historical Buildings Using the Basement of a Medieval Town Hall as an Example" December 2017( Procedia Engineering 172:363-368). Wroclaw, Poland. 
Piero, B. p., et al.,(2012) "Nano-Materials for the Conservation and Preservation of Movable and Immovable Artworks" January 2012(DOI:10.1260/20474970.1.0.313). Florence, Italy.

Polubarinova, P. I. \& Kochina,(1962) "Theory of ground water movement" Princeton university press, Copyright 1962 (ISBN:9780691651835) New Jersey, U.S.A,

Rabanal, E. M. et al.,(2017)" New nanomaterials for applications in conservation and restoration of stony materials" Vol. 67, Issue 325, January-March 2017 (ISSN-L: 0465-2746). Madrid, Spain

Rowberry, M. (2012)" The monitoring of slow-moving landslides and assessment of stabilization measures using an optical-mechanical crack gauge" Journal of the International Consortium on Landslides Vol. 3 September 2012 (ISSN 1612-510X) Slovakia

Sullivan, M. A.(2016) "Cultural Heritage \& New Media: A Future for the Past" Rev. Intell. Prop. L. 604 Vol. 15 May 2016 ( Iss. 3)

https://repository.jmls.edu/cgi/viewcontent.cgi?article=1392\&context=rip

Sierra, F. A., et al., "New consolidant product based on nanoparticles to preserve the dolomitic Stone heritage". .M. Rogerio Candelera (Ed.), Science, Technology and Cultural Heritage, pp. 139-144. ISBN 9781315712420. (2014)

Talegon, J., et al.,(2012) "Canonical Biplot as tool to detect microclimates in the inner and outer parts of Salamanca Cathedrals" January 2012(ISSN: 0263-2241)

http://hdl.handle.net/10261/180778

Tapete, D. et al., (2013)"Integrating radar and laser-based remote sensing techniques for monitoring structural deformation of archaeological monuments" Journal of Archaeological Science Volume 40, Issue 1, January 2013, Pages 176-189 Italy. https://doi.org/10.1016/j.jas.2012.07.024

United nations educational, scientific and cultural organization (UNESCO ) intergovernmental" committee for the protection of the world cultural and natural heritage- WHC/2/revised February 1996

Veronique, H. B.,(2016) "Maintenance in historic buildings in Belgium and Portugal" Dissertation to obtain the Master Science Degree in Civil Engineering University of Lisbon, Belgium, Portugal

Winkler, E. M. (1988) "Practical Building Conservation" English Heritage Technical Handbook, -Vol.22, Gower Technical Press, 1988 (Paris No. 72495) - Technology $\&$ Engineering - 114 pages .

Zehnder, K.\& Arnold, A.(1985) "Crystallization and habits of salt efflorescence on walls" II,Vth international congress on deterioration and conservation of stone, (Paris No. 72495) Lausanne, 25-27.9.1985, vol.1, pp269-277

Designboom. com (2018). scientists discover that the shape of the great pyramid of giza can focus electromagnetic energy, retrieved from;

https://www.designboom.com/design/scientists-discover-shape-great-pyramidgiza-focus-electromagnetic-energy-07-31-2018/

$\begin{array}{llll}\text { step } & \text { (2021). } & \text { Ryramid } & \text { Retrieved }\end{array}$ https://www.google.com.eg/search?q=step+pyramid\&source $=$ lnms\&tbm $=$ isch\&sa $=X \& v e d=2$ ahUKEwjn453ak5_wAhXtVRUIHTunB_wQ_AUoAXoECAEQAw\&biw=1707\&bih=775\&d $\mathrm{pr}=1.13 \#$ imgrc $=\mathrm{CEWMF} 48$ thOeOmM

Step Pyramid | Pyramid of djoser, Ancient Egypt history, Ancient Egyptian architecture. (2021). Retrieved from https://www.pinterest.com/pin/564357397028793021/ 
inside step pyramid (2021). Retrieved from https://www.google.com.eg/search?q=inside+step+pyramid\&tbm=isch\&hl=en\&sa=X\&ved=2 ahUKEwiy9auEl5_wAhUNihoKHaOgCAoQrNwCKAB6BQgBEOIB\&biw=1688\&bih=775\# imgrc $=$ tgmqC-GqsnpO0M

All Saints Church, Little Kimble England (2021). Retrieved from https://www.google.com/search?q=All+Saints+Church,+Little+Kimble+England\&source=ln ms\&tbm=isch\&sa $=X \& v e d=2 a h U K E w j b o e S g m Z \_w A h W w l-$ AKHZ1wAe8Q_AUoAnoECAEQBA\&biw=1396\&bih=634\#imgrc=Mft5ZsQaeUH0xM

Schematic drawing of summaries effect water on masonry wall. (2021). Retrieved from https://www.google.com.eg/search?q=Schematic+drawing+of+summaries+effect+water+on+ masonry+wall\&source $=1 n m s \& t b m=i s c h \& s a=X \& v e d=2 a h U K E w j B q t S K m p \_w A h U A V B U I H$ eZRCYgQ_AUoAXoECAEQAw\&biw=1707\&bih=775\&dpr=1.13\#imgrc=z7T4kay0WvLA $\mathrm{YM}$

Depth to the water table record by radar. (2021). Retrieved from https://www.google.com/search?q=Depth+to+the+water+table+record+by+radar\&source=ln ms\&tbm $=i s c h \& s a=X \& v e d=2 a h U K E w j e 2 e b q m p \_w A h V B t 3 E K H Y T N A p U Q \_A U o A X o E C A$ EQAw\&biw $=1396 \&$ bih=634\#imgrc $=$ wm7DB8aFg8xFIM

Schematic drawing of summaries effect water on masonry wall - Google Search. (2021). Retrieved from https://www.google.com.eg/search?q=Schematic+drawing+of+summaries+effect+water+on+ masonry+wall\&source $=$ lnms $\&$ tbm $=$ isch $\& s a=X \& v e d=2$ ahUKEwjBqtSKmp_wAhUAVBUIH eZRCYgQ_AUoAXoECAEQAw\&biw=1707\&bih=775\&dpr=1.13\#imgrc=z7T4kay0WvLA $\mathrm{YM}$

Custom WSN hardware. (2021). Retrieved from https://www.google.com/search?q=Custom+WSN+hardware\&source=lnms\&tbm=isch\&sa=X \&ved=2ahUKEwi4-

JD0np_wAhUEixoKHVJ4DZkQ_AUoAXoECAEQAw\&biw=1396\&bih=634\#imgrc=I0f5P U_un5ELBM

nmr spectrometer diagram. (2021). Retrieved from https://www.google.com/search?q=nmr\%20spectrometer\%20diagram\&tbm=isch\&hl=en\&sa= X\&ved=0CJQBEKzcAigAahcKEwjg8en_n5_wAhUAAAAAHQAAAAAQCQ\&biw=1381\& bih=634\#imgrc=w2URpbLqPjpfEM

high-resolution crack analysis sensor system and the revolutionary digital CMOSens $®$ technology. (2021). Retrieved from https://www.google.com/search?q=highresolution+crack+analysis+sensor+system+and+the+revolutionary+digital+CMOSens $\% \mathrm{C} 2 \%$ AE+technology\&source $=$ lnms\&tbm $=$ isch\&sa $=X \& v e d=2 a h U K E w j p q f S i o Z \_w A h U I 5 a w K H e$ xpCasQ_AUoAXoECAEQAw\&biw=1396\&bih=634\#imgrc=g13rPTfYeDcmjM 